\title{
Hotair and Malat1 Long Noncoding RNAs regulate Bdnf Expression and Oligodendrocyte Precursor Cells Differentiation
}

\author{
Fatemeh Khani-Habibabadi ${ }^{1}$, Leila Zare ${ }^{2}$, Mohammad Ali Sahraian ${ }^{3}$, Mohammad Javan ${ }^{2}$, \\ Mehrdad Behmanesh ${ }^{1}$ * \\ ${ }^{1}$ Department of Genetics, Faculty of Biological Sciences, Tarbiat Modares University, Tehran, Iran \\ ${ }^{2}$ Department of Physiology, Faculty of Medical Sciences, Tarbiat Modares University, Tehran, Iran \\ ${ }^{3}$ MS Research Center, Neuroscience Institute, Tehran University of Medical Science, Tehran, Iran
}

\section{Corresponding authors:}

\section{Mehrdad Behmanesh:}

Department of Genetics, Faculty of Biological Sciences, Tarbiat Modares University, P.O. Box: 14115-154, Tehran, Iran, Tel: +98-21-82884451, Fax: +98-21-8288-4717.

E-mail: behmanesh@modares.ac.ir

\section{Mohammad Javan:}

Department of Physiology, Faculty of Medical Sciences, Tarbiat Modares University, Tehran, Iran

P.O. Box: P.O. Box 14115-331, Tehran, Iran, Tel: +98-21-82884522, Fax: +98-21-8288-4528.

E-mail: $\underline{\text { miavan@modares.ac.ir }}$ 


\section{Abstract:}

BDNF has remarkable protective roles in the central nervous system to ensure neurons and glial cells survival and proper functions. The regulatory processes behind the BDNF expression have not been revealed completely. Here, it was explored whether Malat1 and Hotair IncRNAs play roles in the regulation of Bdnf expression level, modification of fingolimod downstream pathway, and oligodendrocytes precursor cells maturation. By Hotair and Malat1 downregulation, their regulatory mechanism on Bdnf expression was investigated. Immunostaining and RT-qPCR assays were employed to assess the effects of fingolimod and IncRNAs on OPCs maturation. The results represented that Hotair and Malat 1 IncRNAs may regulate Bdnf expression in primary glial cells significantly, and also can coordinate fingolimod stimulatory effect on Bdnf expression. Furthermore, Malat1 may have a role in the last stages of the intrinsic oligodendrocyte myelination. Here it was demonstrated that these IncRNAs have critical roles in the Bdnf level, fingolimod mechanism of action, and OPCs maturation. Understanding the regulatory mechanism of neurotrophins leads to a better comprehension of the neurodegenerative disorders pathogenesis and designing more effective treatments.

Keywords: Oligodendrocytes precursor cells; Myelin; Brain-derived neurotrophic factors; long noncoding RNAs; Fingolimod. 


\section{Introduction}

Brain-derived neurotrophic factor (BDNF) is a member of the neurotrophins family with some well-known roles such as regulation of neural development, differentiation, survival, and synaptic plasticity. There are two types of secreted BDNF, pro-BDNF and mature-BDNF [1]. By binding to the P75 receptor, pro-BDNF stimulates pro-apoptotic effects, while mature-BDNF triggers pro-survival pathways through binding to the TrkB receptor [2]. By BDNF production, astrocytes, microglia, brain-resident macrophages, and infiltrated lymphocytes in the brain lesion can protect neural survival $[3,4]$. It is well demonstrated that BDNF induces oligodendrocyte precursor cells (OPCs) regeneration, and differentiation [5, 6].

In the central nervous system (CNS), oligodendrocyte cells are responsible for myelin production. As immune cells cross the blood-brain barrier (BBB) and ignite an inflammatory environment, oligodendrocytes, which are the most sensitive glial cells to inflammatory conditions, undergo apoptosis that results in myelin loss and plaque formation [7]. Damaged myelin leads to lesions and plaque formation, which interfere with the regular signal transmission and prone axons to the inflammatory milieu [8]. It has been suggested that myelin repair has two general steps, OPCs recruitment to the lesion region and differentiation into mature oligodendrocytes. Defects in any of these two pathways have been reported in demyelinating disorders. The remyelination process can occur to some extent, but its rate and efficiency decrease over time [9].

A destructive-protective role has been considered for astrocytes in demyelinating disorders. It is suggested that the inflammatory conditions in the CNS affect the astrocytes activation and genes expression profile. Severe astrogliosis prevents CNS healing by releasing more inflammatory cytokines; however, mild astrogliosis triggers the production of protective and growth factors such as BDNF, which protects newly synthesized myelin proteins [10, 11]. Like astrocytes, growing evidence shows the heterogeneous nature of microglia in this phenomenon. 
By activation, microglia can be developed into two distinct phenotypes, M1 and M2 in which, M1 microglia play a cytotoxic role by producing inflammatory factors such as IL-6, IL-1 $\beta$, and TNF $\alpha$ in the advanced stages of the disease. However, the M2 phenotype is more prominent in the early stage and plays roles by producing protective factors such as BDNF and IGF-1 [12].

Fingolimod acts as a S1P agonist and targets the signaling pathway of the sphingosine-1phosphate GPCR receptor. Phosphorylated fingolimod can bind to all types of S1PR except S1P2 and cause ubiquitination, internalization, and degradation of the receptor. Hence, lymphocytes do not respond to the S1P ligand gradient and get trapped in the lymph nodes [13]. It is well declared that through binding to S1P receptors on microglia, oligodendrocytes, astrocytes, and neurons, fingolimod plays protective roles in the CNS, including cell survival, OPCs differentiation, myelin repair, restoring synaptic function, a reduction in the secretion of inflammatory cytokines, and an increase in the neurotrophins production $[14,15]$.

Long non-coding RNAs (IncRNAs) are a class of non-coding RNAs that are longer than 200 nucleotides and cannot encode proteins [16]. Current studies have shown the important roles of IncRNAs in different human diseases such as neurodegenerative and demyelinating disorders [17]. In our previous study by bioinformatics analysis, it was demonstrated that there is a positive correlation between BDNF gene expression and two IncRNAs HOTAIR (HOX Transcript Antisense RNA) and MALAT1 (Metastasis Associated Lung Adenocarcinoma Transcript 1) in neurodegenerative disorders [18].

It has been reported that HOTAIR IncRNA binds to the PRC2 and LSD1 complexes and directs them to their target loci resulting in gene silencing. Besides, HOTAIR can sponge miRNAs and inhibit their binding to their downstream target genes [19]. MALAT1 IncRNA, also known as NEAT2, is one of the most abundant nuclear IncRNAs and is highly conserved among species. Like HOTAIR, MALAT1 can regulate target genes through two distinct mechanisms: sponging 
their regulating miRNAs and conductance of the PRC2 complex, which induces histones methylation and gene suppression [20].

LncRNAs research has been becoming a hotspot in neuroscience; however, a few studies have considered their roles in the glial cells function and OPCs maturation. This study employed a combination of in silico, molecular and cellular techniques, including homology analysis, gene downregulation, primary glial culture preparation, immunocytochemistry, and RT-qPCR, to decipher the potential regulative roles of Hotair and Malat1 IncRNAs in the Bdnf expression in glial cells and oligodendrocytes myelination. The obtained results demonstrate that Hotair and Malalt1 IncRNAs may significantly regulate Bdnf expression in glial cells. Also, Malat1 can plays a role in the myelination process. These data pave the way to a better illustration of networks behind the OPCs differentiation and can serve as possible targets for future therapies of demyelinating disorders.

\section{Materials and methods:}

\subsection{Preparation of mixed glia culture}

Primary glial cells were collected from P0 Wistar rat pups. Briefly, six rat pups' brain was dissected mechanically by scalpel blade and passed through $40 \mu \mathrm{m}$ cell strainer (SPL Life Sciences, Korea). The cell suspension was then cultured on Poly-L-lysine (PLL)-coated (Sigma, USA) T75 cell culture flasks in DMEM High Glucose, FBS 10\%, supplemented with 50 U $\mathrm{ml}^{-1}$ penicillin and $50 \mu \mathrm{g} \mathrm{ml}{ }^{-1}$ streptomycin (Gibco) at $37^{\circ} \mathrm{C}$ under a humidified atmosphere containing 5\% CO2. Every 2-3 days the medium was changed completely until the culture reached to ideal confluency [21]. The procedures of this research were approved by the ethics community of Tarbiat Modares University (ID: IR.TMU.REC.1396.607). 


\subsection{OPCs isolation and differentiation}

Approximately after 10 days, the primary glial culture reach to enough confluency with small sparkling OPCs on the top of the astrocytes layer. In this study, the OPCs were isolated for further analyses of fingolimod effects on oligodendrocytes maturation by the shaking method. This isolation method was based on differential adherent properties of glial cells. For this purpose, the flasks were shaken for 1 hour at 200 rpm to detach and discard microglia cells. Then, to detach OPCs from the astrocyte layer the flasks were incubated at $37^{\circ} \mathrm{C}$ and $5 \% \mathrm{CO}_{2}$, while shaking at 220 rpm overnight. The cell suspension was transferred by a pipette to an untreated petri dish and incubated for 30 minutes to gain better OPCs isolation by differential adhesion properties of contaminating astrocytes and microglia [21]. Unattached OPCs were centrifuged at $1200 \mathrm{rpm}$ for 5 min. Then, 10,000 OPCs were seeded in 4-well PLL-coated plates in proliferative medium, containing DMEM/F-12 medium, L-Glutamax (Gibco, USA) and Sodium pyruvate (Sigma, USA), supplemented with $20 \mathrm{ng} / \mathrm{mL}$ human recombinant basic fibroblast growth factor (bFGF; Invitrogen, USA), $20 \mathrm{ng} / \mathrm{mL}$ epidermal growth factor (EGF; Invitrogen, USA), and $20 \mathrm{ng} / \mathrm{mL}$ Platelet-derived growth factor (PDGF, Invitrogen, USA) for 3 days at $37^{\circ} \mathrm{C}$ under a humidified atmosphere containing 5\% CO2. To induce OPCs differentiation, the proliferation medium was replaced with the differentiation medium including B-27 (Gibco, USA) supplemented with IGF-1 (10 ng/ml, Invitrogen, USA) and T3 (40 ng/ml, Invitrogen, USA) instead of growth factors, and till the end of the differentiation process, half of the differentiation medium was refreshed every other day [21, 22].

\subsection{Fingolimod treatment}

To explore the fingolimod (Sigma, USA) cytotoxicity effects, the glia cells were treated with different concentrations of fingolimod $(0 \mathrm{nM}, 5 \mathrm{nM}, 25,50 \mathrm{nM}, 75 \mathrm{nM}$, and $100 \mathrm{nM}$ diluted in HPLC-grade ethanol). Based on obtained result of cytotoxicity assay concentration of $20 \mathrm{nM}$ 
fingolimod was chosen for treating of Primary glial culture and OPCs gene expression profile, proliferation, and differentiation.

\subsection{Immunostaining}

For immunostaining, the medium was removed, and the cells were fixed by paraformaldehyde for 20 minutes incubation at room temperature. To increase cell permeability, Triton $0.2 \%$ and 0.5\% was used for cytoplasmic markers (GFAP, Iba1, PAX6, and PLP) and nuclear markers (Olig2), respectively. Then, the first antibodies, including Anti-MBP antibody (1:200, Santa Cruz sc-271524, USA), Anti-Olig2 antibody (1:200, Abcam Inc. ab9610, USA), Anti-GFAP antibody (1:300, Dako Z0334, USA), and Anti-Aba1 antibody (1:200, Wako 019-19741, USA) were dissolved in NGS $10 \%$ and incubated overnight at $4{ }^{\circ} \mathrm{C}$. The Alexa Fluor ${ }^{\circledR} 568$ secondary antibodies, including goat anti-mouse, and goat anti-rabbit antibodies (1:1000, Life Technologies, A11004 and A11036, USA), were used, and Nuclei were stained by $0.5 / \mathrm{g} / \mathrm{ml}$ DAPI [23]. The fluorescent signals were detected by a fluorescent microscope (Olympus, Japan).

\subsection{Cell Proliferation and Viability Assay}

The AlamarBlue® assay was employed to measure fingolimod effects on cells proliferation, survival, and cytotoxicity. For this purpose, OPCs were treated with different concentrations of drug fingolimod. After 4 hours, the adsorption was measured at 540 and 630 by an ELISA reader (BioTek, USA) [24].

\subsection{Gene expression analyses}

Cell total RNA was extracted using the RiboEX solution (GeneAll, Seoul, Korea), and its quality and quantity were measured by spectrophotometry and 1.5\% agarose gel electrophoresis. 
DNase I (Fermentas, USA) treatment was performed on RNA samples to remove any genomic DNA contamination. $3 \mu \mathrm{g}$ of total RNAs was applied to synthesize the first strand of cDNA using M-MulV reverse transcriptase (Thermo Scientific, USA) by oligo dT, and random hexamer as primers (MWG, Germany) according to the manufacturer's instruction. Gene expression analysis was performed using a StepOne ${ }^{\mathrm{TM}}$ PCR system (Applied Biosystem/MDS SCIEX, Foster City, CA, USA), with $10 \mathrm{ng}$ cDNA, $5 \mu \mathrm{l}$ of $2 \mathrm{X}$ SYBR ${ }^{\circledR}$ Green master mix (Solis BioDyne, Estonia), and $4 \mathrm{pM}$ of each forward and reverse primers up to final reaction volumes of $10 \mu \mathrm{l}$. Differential gene expression analysis was assessed using the $2^{-\Delta \mathrm{CT}}$ method [25]. The relative expression of $B d n f$ (forward: 5-AGGGAGTGAAGATACCATCAGC-3 and reverse: TATGAGAGCCAGCCACTGACC-3), Hotair (forward: 5-GATTTCAAACTGAGCCCCGATG-3, reverse: 5-CAGGTTTAAGAGAGCCACCCAA-3), and Malat1 (forward: 5ACAAGACCACAGCTCAGTAGC-3, reverse: 5-CCAAGTCTGCTATGTCCACCTG-3) genes were normalized to the housekeeping gene (actin, beta) Actb (forward: 5ATGTGGATCAGCAAGCAGGA-3, reverse: 5- AAAGGGTGTAAAACGCAGCTC-3) (Metabion, Germany). With the help of homology search in sequence databases of mice and rats' genome, the sequences of target genes were found and specific primers based on them were designed. All of the samples were tested at least in duplicate and the specificity of qPCR reactions was verified by melting curve analysis and running of amplification products on $12 \%$ polyacrylamide gel electrophoresis.

\subsection{Gene silencing with DNAzyme}

In this study, a single-stranded DNA sequence with an approximate length of 35 nucleotides, called DNAzyme, was used to reduce the expression of target genes [26]. Oligo 7 (DBA Oligo, USA), SnapGene (GSL Biotech LLC, USA) software, and NCBI-Blast were used to design these oligonucleotides based on the homology searched sequenced. Also, secondary structures 
formation within the target region of RNAs was checked by the RNAfold webserver [27]. To down-

regulate IncRNAs, The Hotair DNAzymes

GGCATTGGTAAGGCTAGCTACAACGAGACACTCTCT-3

and

$5-$

GAAATAGCCAGGCTAGCTACAACGATGTGTCTCT-3) and Malat1 DNAzymes

$(5-$

CCTCATTCCCAGGCTAGCTACAACGACCAGCATTTG-3

and

$5-$

GCAATCCCAGGCTAGCTACAACGACCCAACAGCTT-3) were used (Metabion Company,

Germany). Then, the cells were transfected with $5 \mathrm{nM}$ DNAzymes by INTERFERin® reagent

(Polyplus, USA) according to the manufacturer's instructions. After 24 and 48 hours of incubation,

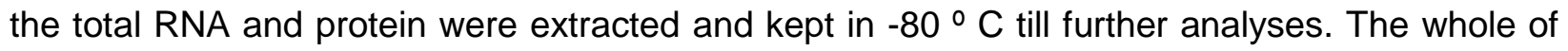
experiment was repeated at least twice.

\subsection{Western Blotting}

Cells were lysed in RIPA buffer (Cyto Matin Gene Co., Iran) according to the manufacturer's instructions. $20 \mu \mathrm{g}$ of total cell proteins were run in a 12\% SDS-polyacrylamide gel and blotted to the PVDF membrane (Bio-Rad, USA). Membranes were incubated overnight at $4{ }^{\circ} \mathrm{C}$ with mature BDNF primary antibody (ThermoFisher OSB00017W, USA) followed by an hour incubation with HRP goat anti-rabbit secondary antibodies (Santa sc-2004, USA) at room temperature. After chemiluminescence visualization, reprobing procedure was done by $0.2 \mathrm{M} \mathrm{NaOH}$ for 5 minutes. Next, beta-actin antibody (Santa Cruz sc-47778, USA) as the internal control was applied on the membrane at $4{ }^{\circ} \mathrm{C}$ overnight, followed by an hour incubation with HRP goat anti-mouse secondary antibody (Santa Cruz sc-2005, USA) at room temperature [28]. Blots were visualized by chemiluminescence (ECL; Cyto Matin Gene, Iran) and the obtained bands were quantified using ImageJ software. 


\subsection{Statistical analyses}

For two-group and multiple-group analyses, comparisons were applied by unpaired t-test and ordinary one-way ANOVA with Tukey's multiple comparisons test, respectively. For cell survival assay, ordinary two-way ANOVA was employed with Dunnett's multiple comparison test. All of the statistical analyses and graphs visualizations were accomplished by Prism - GraphPad 7 (GraphPad Software, USA). Error bars represent standard deviation, and the significance level was assigned as $\mathrm{p}<0.05$ (two-tailed test).

\section{Results}

\subsection{Fingolimod treatment did not affect glial cell survival}

To analyze the fingolimod effects on the glial cells, the primary glial culture was obtained from the rat pups' brain (Fig. 1, a). The immunostaining results demonstrated the presence of Iba1+ cells (Microglia, Fig. 1, b), GFAP ${ }^{+}$cells (Astrocytes, Fig. 1, c), Olig2+ (Oligodendrocytes lineage, Fig. 1, d), and $\mathrm{MBP}^{+}$cells (mature oligodendrocytes, Fig. 1, e). Signal quantification for each specific cell marker antibodies determined that the microglia are the most abundant cell type in the culture (54\%). OPCs and astrocytes consist about $27 \%$ and $17.5 \%$ of cells in the primary culture, respectively; however, the mature oligodendrocytes were scarce $(0.85 \%)$. The presented results are obtained from at least three times independent biological repeated (Fig. 1, f).

Proliferation assay demonstrated that fingolimod treatment had no cytotoxic effects on glial cells at $5,25,50,75$, and $100 \mathrm{nM}$ concentrations. Although the percentage of alive cells dropped slightly by increasing the concentration of fingolimod, this decrease did not pass the significance level. Also, there was no variation in obtained result in the time course analyses (Fig. 1, g). Since all of the treated concentrations are below the IC50, based on the previous works, $20 \mathrm{nM}$ concentration was selected for further analysis [29]. 


\subsection{Hotair and Malat1 IncRNAs downregulation decreased the Bdnf expression.}

To explore the regulatory role of Hotair and Malat1 IncRNAs on Bdnf mRNA expression regulation, their specific DNAzymes were designed to decline their expression. Hotair and Malat1 specific DNAzymes were able to decreased their target mRNAs expression level significantly, Fig. 2a \&b (0.18-fold, $p=0.004$, and 0.39-fold, $p=0.025$, respectively). Then, the Bdnf expression level was measured independently and concurrent with Hotair and Malat1 downregulation. The results demonstrated that the expression of Bdnf level is affected by Hotair $(0.19$-fold, $p=0.010)$ and Malat1 (0.47-fold, $\mathrm{p}=0.036)$ RNA level downregulation (Fig. 2, c).

\subsection{Hotair and Malat1 IncRNA downregulation abort the Bdnf upregulation by fingolimod treatment.}

Glial primary culture treatment by fingolimod upregulated Bdnf expression (1.7-fold, $p=0.001$; however, concurrent fingolimod treatment with downregulation of Hotair $(0.0015$-fold, $\mathrm{p}<0.0001)$ or Malat1 (0.013-fold, $\mathrm{p}<0.0001)$ IncRNAs not only did not induce Bdnf expression but also reduce its mRNA level (Fig. 2, d). This result indicates that Hotair and Malat1 IncRNA play a pivotal role in inducing Bdnf through fingolimod treatment.

\subsection{Hotair and Malat1 IncRNA may regulate each other in a feedback loop.}

To see if there is any regulatory feedback loop between Hotair and Malat1 IncRNAs, the RNA level of each IncRNA was measured when the other one had been downregulated. The results suggested that a decline in the level of Malat1 led to downregulation of Hotair IncRNA (0.02-fold, $\mathrm{p}=0.0005$ ) (Fig. 2, e). Likewise, downregulation of Hotair would lead to a decrease in Malat1 RNA level (0.23-fold, $p=0.03$ ) (Fig. $2, f)$. These data suggest that there might be a regulatory feedback loop between these two IncRNAs. 


\subsection{OPCs were isolated by the shaking method.}

The shaking method yielded a highly efficient isolation of OPCs from primary glial culture for further maturation analyses. The whole OPCs purification procedure is depicted in Fig. 3, a. Invert light microscopic images demonstrated the bipolar morphology of isolated OPCs (Fig. 3, b). Immunocytostaining results revealed that the majority of purified culture is consists of Olig2 ${ }^{+}$cells (Fig. 3, c). Quantified immunostaining results represented that the yield of isolation was more than 94\% (Fig. 3, d). The purification procedure was repeated at least three times.

\subsection{Fingolimod induced OPCs maturation but not their proliferation.}

The ICC analysis demonstrated an increasing in $\mathrm{MBP}^{+}$cell after 1 week of fingolimod treatment (Fig. 4, a) compare to the control group (Fig. 4, b). Quantified immunofluorescent signals indicated 2.8-fold increase in the percentage of myelinated oligodendrocytes, which was promoted by fingolimod intervention ( $p=0.002$, Fig. $4, c)$. In contrast, the proliferation test did not represent any significant alteration not only in oligodendrocytes proliferation capability but also in their survival in 1 week of fingolimod supplementation (Fig. 4, d).

\subsection{Fingolimod induced Bdnf and Hotair expression along with oligodendrocytes maturation.}

The fingolimod mechanism of action in inducing OPCs differentiation was analyzed by exploring its possible role in regulating Hotair, and Malat1 IncRNAs and Bdnf gene expression. Hotair expression upregulated during oligodendrocyte differentiation in response to fingolimod treatment (8.4-fold, $p=0.003$, Fig. 4, e); however, its expression was not affected in untreated cells. In contrast to Hotair, although Malat1 expression was not affected by fingolimod treatment, 
this IncRNA is unregulated along with time in both control and treated cultures $(2.5$ fold, $p=0.002$, Fig. 4, f).

BDNF mRNA and protein expression level were evaluated in control and treated OPCs after 2 and 7 days of fingolimod intervention. RT-qPCR results represented that fingolimod increased Bdnf mRNA level significantly after two (2.4-fold, $\mathrm{p}=0.03)$ and seven $(2.5$-fold, $\mathrm{p}=0.04)$ days of treatment. Without fingolimod treatment, Bdnf expression was not raised along with oligodendrocytes maturation at mRNA level. (Fig. 4, g). While, western blot data represented that the expression of mature Bdnf was not altered following fingolimod treatment $(P>0.05$, Fig. $4, h$ \& i.

\section{Discussion}

In demyelinating disorders, one of the main problems is that OPCs remain undifferentiated in CNS plaques and do not respond to differentiation stimulators [9]. As a possible therapeutic intervention, fingolimod and Bdnf treatment have shown considerable effects on the plaque remyelination process $[1,2,5,6]$. Deciphering regulatory pathways involved in OPCs maturation can lead to a better comprehension of demyelinating disorders pathogenesis and facilitates developing new treatments for patients. Moreover, conserved sequences among species is as an indicative for critical preserved functions. Given the conserved sequences of HOTAIR and MALAT1 IncRNAs among humans, mice, and rats [30], these genes may orchestrate conserved and essential regulatory pathways amongst these species.

Previously, it was demonstrated that in cultured neurons, fingolimod treatment induced Bdnf expression and hindered neuronal death [31]. Also in EAE mice fingolimod ameliorate memory impairment [32]. Furthermore, in mice Multiple Sclerosis and Alzheimer' disease models, fingolimod oral administration restored the expression level of Bdnf in the cerebral cortices and 
hippocampi [33]. Similarly, in this study, fingolimod treatment increased Bdnf expression in primary glial and OPCs cells.

The obtained results illustrated that fingolimod treatment induces Bdnf expression in glial cells, especially astrocytes and microglia. Previous studies also have shown a modulatory role for fingolimod on astrocyte-secreting factors through inhibiting anti-inflammatory cytokines production and stimulating the secretion of BDNF neurotrophic factor, which prevents neural loss [33, 34]. Moreover, fingolimod modulates microglia-secretory factors and switches microglia to M2 phenotype by activating STAT3 pathway and increasing the M2 profile expression, including GDNF, BDNF, IL-10, and TGF- $\beta$ [35]. Microglia play an essential physiological role in synaptic plasticity, memory, and learning through the production of BDNF [36] indicating their possible role as a double-edged sword in brain. Therefore, fingolimod treatment induces astrocytes and microglial anti-inflammatory and protective roles to maintain the physiologic milieu of the CNS and protect neurons.

Overproduced Bdnf by astrocytes and microglia also play roles in OPCs maturation and myelin repair. In previous studies it was confirmed that Bdnf treatment increases oligodendrocyte proliferation, differentiation, remyelination, neural survival, and axonogenesis $[5,6,37]$ through activation of the TrkB receptor downstream signaling pathway [37, 38]. Altogether, fingolimod induces protective aspects of microglia and astrocytes, including anti-inflammatory and neurotrophic factors expression, which in turn have modulatory functions on neural survival and myelin repair.

Given the critical roles of Bdnf in the CNS maintenance, understanding its regulatory systems can be beneficial for finding new therapeutic approaches. Among gene regulatory mechanisms, IncRNAs are an emerging area in RNA research. It is well understood that IncRNAs control different aspects of RNA expression such as, transcription initiation, RNA stability, and translation efficacy in the cytoplasm [16]. In this study, analyzing the Bdnf regulatory system demonstrated that a decrease in the expression level of Hotair and Malat1 IncRNAs resulted in 
lower Bdnf expression. This data suggests these two IncRNAs may participate in the fingolimod downstream signaling pathways leading to regulation of target genes, including Bdnf through a IncRNA-mediated mechanism such as the competitive endogenous RNA (ceRNA). The competitive endogenous RNA (ceRNA) hypothesis can interpret this association among Bdnf expression and Hotair and Malat1 IncRNAs. The ceRNA hypothesis represents the interaction among miRNAs, IncRNAs, and mRNAs through microRNA binding sites (MREs) [39].

Simultaneous Hotair and Malat1 IncRNAs downregulation under fingolimod treatment, not only did not enhanced Bdnf expression but also decreased its expression level compare to DNAzyme treated groups through an unknown mechanism.

Also, this study showed that there might be a regulatory feedback loop between Hotair and Malat1 IncRNAs. Downregulation of each IncRNA results in reducing the expression level of the other one. The ceRNA hypothesis can interpret this positive regulatory feedback loop between Hotair and Malat1 IncRNAs. This hypothesis indicates that IncRNAs and mRNAs regulate each other by competing to scavenge for the restricted miRNA pool. Hotair may regulate Malat1 by sponging miR-217, which has a confirmed binding site on Malat1 sequencing [40]. Furthermore, the downregulation of Malat1 enhances mature miR-1 expression even more than its precursors. The existence of the miR-1 binding site on Malat1 IncRNA indicates that this IncRNA increases Hotair level through sponging miR-1 [41]. CeRNA hypothesis may justify the observed positive regulatory feedback loop between these two IncRNAs.

Malat1 is expressed ubiquitously and its expression level is higher than many coding genes, even comparable to a highly transcribed $\beta$-Actin housekeeping gene [30]. On the contrary, Hotair is a very low abundant IncRNA not only in normal tissues but also in different diseases [42]. These findings are in line with our results. The issue to consider is that a IncRNA abundance should not be misunderstood with its importance. As for the low expressed Hotair, there is accumulating evidence for its prominent roles in development, chromatin modification, pathogenesis, and creating RNA scaffold, to mention some [43]. 
More than stimulatory effects on Bdnf expression, fingolimod also can increase myelin formation $[14,15,29,32]$. The obtained data showed that fingolimod increase OPCs differentiation, however, the $\mathrm{MBP}^{+}$cells are present in the untreated group with fewer number. After 7 days, 3.7 percent of OPCs in the differentiation medium expressed MBP marker without fingolimod treatment. In another study, after 12 days of OPCs maintenance in differentiation medium, the expression level of PDGFaR reduces by half and the MBP was expressed in about 20 percent of total cells [44]. OPCs can differentiate in differentiation medium without any further stimuli; however, different substances can facilitate this process and make it more efficient. Here, it was showed that adding fingolimod to the differentiation medium have stimulatory effect on MBP expression. As represented by previous studies, Triiodo-L-thyronine (T3), which is one of the differentiation medium ingredients, controls the specification and differentiation of OPCs to the mature oligodendrocytes. T3 promotes and helps the timing of precursor cell differentiation through a currently unknown mechanism [44, 45].

Here, it was demonstrated that fingolimod induces OPCs maturation, but not their proliferation. Given the fact that differentiation and proliferation are two contradictory mechanisms [46], this data indicates that fingolimod hinders OPCs proliferation to trigger the differentiative pathways. Fingolimod treatment stimulated OPCs differentiation and MBP expression concomitant with increasing Bdnf mRNA. Elevated Bdnf level subsequent to fingolimod treatment has demonstrated in previous researches [31, 47, 48]. Also, protective role of Bdnf in the CNS has been clearly declared $[1,2,5,6]$. Altogether, OPCs undergo maturation by fingolimod treatment, and the Bdnf neurotrophic factor may play role in their differentiation process. Unchanged mature Bdnf protein expression during OPCs differentiation was observed may be due to the pro-Bdnf process in the secretory vesicles, so the elevation of mature-Bdnf cannot be detected because the mature Bdnf is secreted immediately from the cell [47].

More than Bdnf, seven days of fingolimod treatment enhanced the expression of Hotair simultaneously with MBP expression. Hence, this result suggests that long-term of fingolimod 
treatment induces Hotair expression in OPCs which may play a role in their differentiation process. Dissimilar to Hotair IncRNA, Malat1 expression increased independently from fingolimod treatment, indicating that Malat1 IncRNA may play an intrinsic role in the OPCs maturation in differentiation medium. Another interpretation for this hesitated response is the selected time window [49]. There is a possibility for a short-term response of Malat1 and Hotair in response to fingolimod treatment, so they cannot be assessed readily.

Upon fingolimod treatment, increased Bdnf expression did not match with alteration in Malat1 and Hotair IncRNAs expression level. Subsequently, unlike glial culture, there is no correlation between Bdnf and IncRNAs expression levels. Given that microglia and astrocytes constitute the majority of the primary culture, this observed correlation in the downregulation experiment belongs to astrocytes and microglia cells. Future studies on animal models of demyelinating disorders could provide valuable data on the Malat1 and Hotair IncRNAs mechanism of action in the remyelination process.

\section{Conclusion}

The results of the current study showed that Bdnf regulatory mechanism probably is distinct in different types of glial cells. As mentioned above, Hotair and Malat1 may control Bdnf expression level significantly, in primary glial cells. Also, it was demonstrated that Hotair and Bdnf may play role in fingolimod-induced OPCs differentiation. Nevertheless, Malat1 takes part as a natural modulator in OPCs differentiation. Given the obtained results, Hotair and Malat1 may play critical regulatory role in fingolimod mechanism of action, Bdnf expression and oligodendrocytes differentiation. 


\section{Declarations:}

\section{Acknowledgment:}

The authors thank Javad Mirnajafi-Zadeh for providing rat pups for this study. We also thank the funding source for their support.

\section{Funding:}

This work was supported by the Iran National Science Foundation and the Department of Research Affairs of Tarbiat Modares University.

\section{Author information:}

\section{Affiliations:}

Department of Genetics, Faculty of Biological Sciences, Tarbiat Modares University, Tehran, Iran

Fatemeh Khani-Habibabadi, Mehrdad Behmanesh

Department of Physiology, Faculty of Medical Sciences, Tarbiat Modares University, Tehran, Iran

Leila Zare, Mohammad Javan

MS Research Center, Neuroscience Institute, Tehran University of Medical Science, Tehran, Iran

Mohammad Ali Sahraian 


\section{Contributions:}

All authors contributed to the study conception and design. Material preparation, data collection and analysis were performed by Fatemeh Khani-Habibabadi, Mehrdad Behmanesh, Leila Zare, and Mohammad Javan. The first draft of the manuscript was written by Fatemeh KhaniHabibabadi and all authors commented on previous versions of the manuscript. All authors read and approved the final manuscript.

\section{Corresponding authors:}

Correspondence to M. Behmanesh and M. Javan.

\section{Ethics declarations:}

\section{Ethics approval:}

The procedures of this research were approved by the ethics community of Tarbiat Modares University (ID: IR.TMU.REC.1396.607).

\section{Availability of data and material:}

The data that support the findings of this study are available on request from the corresponding author.

Code availability: Not applicable.

Consent to participate: Not applicable.

Consent for publication: Not applicable.

Conflicts of interest/Competing interests: None. 


\section{References}

1. Miranda M, Morici JF, Zanoni MB, Bekinschtein P (2019) Brain-derived neurotrophic factor: a key molecule for memory in the healthy and the pathological brain. Front Cell Neurosci 13:363

2. Giacobbo BL, Doorduin J, Klein HC, et al (2019) Brain-derived neurotrophic factor in brain disorders: focus on neuroinflammation. Mol Neurobiol 56:3295-3312

3. Ishii T, Warabi E, Mann GE (2019) Circadian control of BDNF-mediated Nrf2 activation in astrocytes protects dopaminergic neurons from ferroptosis. Free Radic Biol Med 133:169-178

4. Fontanesi C, Kvint S, Frazzitta G, et al (2016) Intensive rehabilitation enhances lymphocyte BDNF-TrkB signaling in patients with Parkinson's disease. Neurorehabil Neural Repair 30:411-418

5. Fletcher JL, Wood RJ, Nguyen J, et al (2018) Targeting TrkB with a brain-derived neurotrophic factor mimetic promotes myelin repair in the brain. J Neurosci 0487-18. https://doi.org/10.1523/JNEUROSCI.0487-18.2018

6. Fletcher JL, Murray SS, Xiao J (2018) Brain-derived neurotrophic factor in central nervous system myelination: a new mechanism to promote myelin plasticity and repair. Int J Mol Sci 19:4131

7. Sospedra M, Martin R (2016) Immunology of multiple sclerosis. In: Seminars in neurology. Thieme Medical Publishers, pp 115-127

8. Lemus HN, Warrington AE, Rodriguez M (2018) Multiple sclerosis: mechanisms of disease and strategies for myelin and axonal repair. Neurol Clin 36:1-11

9. Duncan ID, Radcliff A (2020) Remyelination therapy for demyelinating disease. Nat Rev Neurol 1

10. Kıray H, Lindsay SL, Hosseinzadeh S, Barnett SC (2016) The multifaceted role of astrocytes in regulating myelination. Exp Neurol 283:541-549. https://doi.org/10.1016/j.expneurol.2016.03.009

11. Ponath G, Park C, Pitt D (2018) The Role of Astrocytes in Multiple Sclerosis. Front Immunol 9:217. https://doi.org/10.3389/fimmu.2018.00217

12. Ransohoff RM (2016) A polarizing question: do M1 and M2 microglia exist? Nat Neurosci 19:987-991. https://doi.org/10.1038/nn.4338

13. Barry B, Erwin AA, Stevens J, Tornatore C (2019) Fingolimod rebound: a review of the clinical experience and management considerations. Neurol Ther 8:241-250

14. Chun J, Kihara Y, Jonnalagadda D, Blaho VA (2019) Fingolimod: lessons learned and new opportunities for treating multiple sclerosis and other disorders. Annu Rev Pharmacol Toxicol 59:149-170

15. Pitteri M, Magliozzi R, Bajrami A, et al (2018) Potential neuroprotective effect of Fingolimod in multiple sclerosis and its association with clinical variables. Expert Opin Pharmacother 19:387-395

16. Yao RW, Wang Y, Chen LL (2019) Cellular functions of long noncoding RNAs. Nat Cell 
Biol 21:542-551. https://doi.org/10.1038/s41556-019-0311-8

17. Yang $X$, Wu Y, Zhang B, Ni B (2018) Noncoding RNAs in multiple sclerosis. Clin Epigenetics 10:149. https://doi.org/10.1186/s13148-018-0586-9

18. Khani-Habibabadi F, Askari S, Zahiri J, et al (2019) Novel BDNF-regulatory microRNAs in neurodegenerative disorders pathogenesis: An in silico study. Comput Biol Chem $83: 107153$

19. Hajjari M, Salavaty A (2015) HOTAIR: an oncogenic long non-coding RNA in different cancers. Cancer Biol Med 12:1-9. https://doi.org/10.7497/j.issn.2095-3941.2015.0006

20. Cardamone G, Paraboschi EM, Soldà G, et al (2019) Not only cancer: The long noncoding RNA MALAT1 affects the repertoire of alternatively spliced transcripts and circular RNAs in multiple sclerosis. Hum Mol Genet 28:1414-1428.

https://doi.org/10.1093/hmg/ddy438

21. Chen Y, Balasubramaniyan V, Peng J, et al (2007) Isolation and culture of rat and mouse oligodendrocyte precursor cells. Nat Protoc 2:1044.

https://doi.org/10.1038/nprot.2007.149

22. Medina-Rodríguez EM, Arenzana FJ, Bribián A, de Castro F (2013) Protocol to Isolate a Large Amount of Functional Oligodendrocyte Precursor Cells from the Cerebral Cortex of Adult Mice and Humans. PLoS One 8:e81620. https://doi.org/10.1371/journal.pone.0081620

23. Redmond SA, Mei F, Eshed-Eisenbach Y, et al (2016) Somatodendritic Expression of JAM2 Inhibits Oligodendrocyte Myelination. Neuron 91:824-836.

https://doi.org/10.1016/j.neuron.2016.07.021

24. Kumar P, Nagarajan A, Uchil PD (2018) Analysis of cell viability by the alamarblue assay. Cold Spring Harb Protoc 2018:462-464. https://doi.org/10.1101/pdb.prot095489

25. Livak KJ, Schmittgen TD (2001) Analysis of Relative Gene Expression Data Using RealTime Quantitative PCR and the 2- $\triangle \triangle C T$ Method. Methods 25:402-408. https://doi.org/https://doi.org/10.1006/meth.2001.1262

26. Liu M, Chang D, Li Y (2017) Discovery and biosensing applications of diverse RNAcleaving DNAzymes. Acc Chem Res 50:2273-2283

27. Gruber AR, Bernhart SH, Lorenz R (2015) The ViennaRNA web services. In: RNA bioinformatics. Springer, pp 307-326

28. Kim B (2017) Western blot techniques. In: Molecular Profiling. Springer, pp 133-139

29. Tan B, Luo Z, Yue Y, et al (2016) Effects of FTY720 (fingolimod) on proliferation, differentiation, and migration of brain-derived neural stem cells. Stem Cells Int 2016:

30. Arun G, Aggarwal D, Spector DL (2020) MALAT1 long non-coding RNA: Functional implications. Non-coding RNA 6:22

31. Patnaik A, Spiombi E, Frasca A, et al (2020) Fingolimod modulates dendritic architecture in a BDNF-dependent manner. Int J Mol Sci 21:3079

32. Hunter SF, Bowen JD, Reder AT (2016) The direct effects of fingolimod in the central nervous system: implications for relapsing multiple sclerosis. CNS Drugs 30:135-147 
33. Weinstock LD, Furness AM, Herron SS, et al (2018) Fingolimod phosphate inhibits astrocyte inflammatory activity in mucolipidosis IV. Hum Mol Genet 27:2725-2738. https://doi.org/10.1093/hmg/ddy182

34. Hoffmann FS, Hofereiter J, Rübsamen H, et al (2015) Fingolimod induces neuroprotective factors in human astrocytes. J Neuroinflammation 12:. https://doi.org/10.1186/s12974-015-0393-6

35. Qin C, Fan WH, Liu Q, et al (2017) Fingolimod protects against ischemic white matter damage by modulating microglia toward M2 polarization via STAT3 pathway. Stroke 48:3336-3346. https://doi.org/10.1161/STROKEAHA.117.018505

36. Onodera J, Nagata $\mathrm{H}$, Nakashima A, et al (2021) Neuronal brain-derived neurotrophic factor manipulates microglial dynamics. Glia 69:890-904

37. Edelbrock AN, Àlvarez Z, Simkin D, et al (2018) Supramolecular nanostructure activates TrkB receptor signaling of neuronal cells by mimicking brain-derived neurotrophic factor. Nano Lett 18:6237-6247

38. Zhang J, Yao W, Hashimoto K (2016) Brain-derived neurotrophic factor (BDNF)-TrkB signaling in inflammation-related depression and potential therapeutic targets. Curr Neuropharmacol 14:721-731

39. Liu J, Li H, Zheng B, et al (2019) Competitive endogenous RNA (ceRNA) regulation network of IncRNA-miRNA-mRNA in colorectal carcinogenesis. Dig Dis Sci 64:18681877

40. Zhang W, Qin L, Wang J, et al (2018) HOTAIR promotes proliferation, migration and invasion of esophageal squamous cell carcinoma by regulating MAPK1

41. Han C, Shen JK, Hornicek FJ, et al (2017) Regulation of microRNA-1 (miR-1) expression in human cancer. Biochim. Biophys. Acta - Gene Regul. Mech. 1860:227-232

42. Ezzatizadeh V, Mozdarani H (2019) Does HOTAIR expression level in the peripheral blood have veritably predictive/prognostic impact on breast cancer patients? J Transl Med 17:404. https://doi.org/10.1186/s12967-019-02158-1

43. Bhan A, Mandal SS (2015) LncRNA HOTAIR: A master regulator of chromatin dynamics and cancer. Biochim Biophys Acta 1856:151-164.

https://doi.org/10.1016/j.bbcan.2015.07.001

44. Baldassarro VA, Krężel W, Fernández M, et al (2019) The role of nuclear receptors in the differentiation of oligodendrocyte precursor cells derived from fetal and adult neural stem cells. Stem Cell Res 37:101443. https://doi.org/https://doi.org/10.1016/j.scr.2019.101443

45. Chaudhary P, Marracci GH, Calkins E, et al (2021) Thyroid hormone and thyromimetics inhibit myelin and axonal degeneration and oligodendrocyte loss in EAE. J Neuroimmunol 352:577468. https://doi.org/https://doi.org/10.1016/j.jneuroim.2020.577468

46. Ruijtenberg S, van den Heuvel S (2016) Coordinating cell proliferation and differentiation: Antagonism between cell cycle regulators and cell type-specific gene expression. Cell cycle 15:196-212

47. Smith PA, Schmid C, Zurbruegg S, et al (2018) Fingolimod inhibits brain atrophy and promotes brain-derived neurotrophic factor in an animal model of multiple sclerosis. $J$ Neuroimmunol 318:103-113. https://doi.org/10.1016/j.jneuroim.2018.02.016 
bioRxiv preprint doi: https://doi.org/10.1101/2021.08.09.455020; this version posted August 10,2021. The copyright holder for this preprint (which was not certified by peer review) is the author/funder, who has granted bioRxiv a license to display the preprint in perpetuity. It is made available under aCC-BY-NC-ND 4.0 International license.

48. Segura-Ulate I, Yang B, Vargas-Medrano J, Perez RG (2017) FTY720 (Fingolimod) reverses $\alpha$-synuclein-induced downregulation of brain-derived neurotrophic factor mRNA in OLN-93 oligodendroglial cells. Neuropharmacology 117:149-157

49. Toyoshima A, Yasuhara T, Kameda M, et al (2015) Intra-arterial transplantation of allogeneic mesenchymal stem cells mounts neuroprotective effects in a transient ischemic stroke model in rats: analyses of therapeutic time window and its mechanisms. PLoS One 10:e0127302 
bioRxiv preprint doi: https://doi.org/10.1101/2021.08.09.455020; this version posted August 10, 2021. The copyright holder for this preprint (which was not certified by peer review) is the author/funder, who has granted bioRxiv a license to display the preprint in perpetuity. It is made available under aCC-BY-NC-ND 4.0 International license.

\section{Figure 1}

a

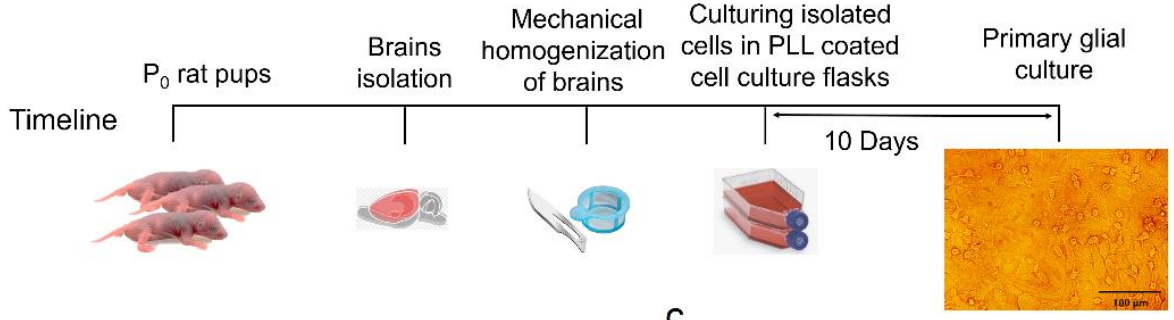

b
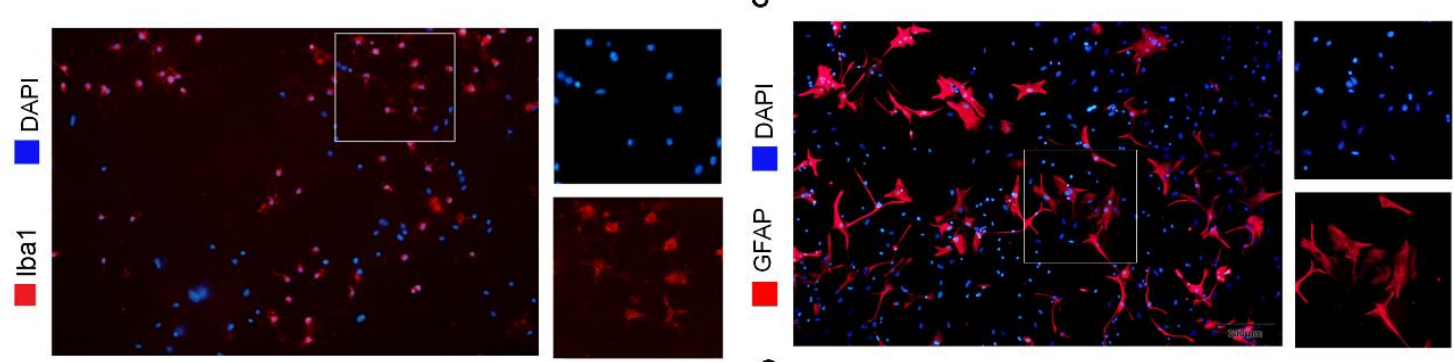

d
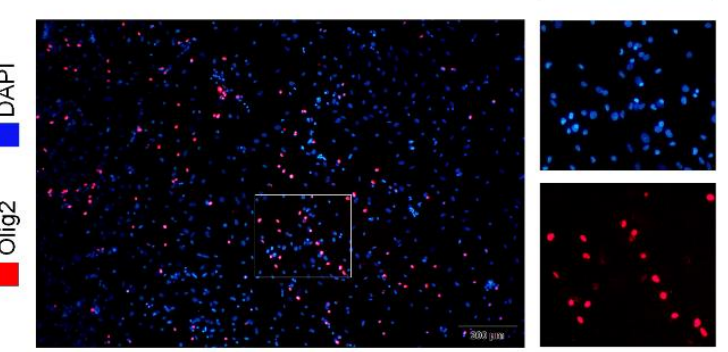

e

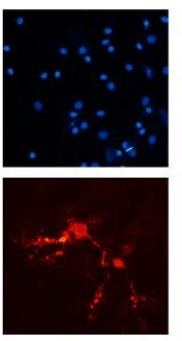

f

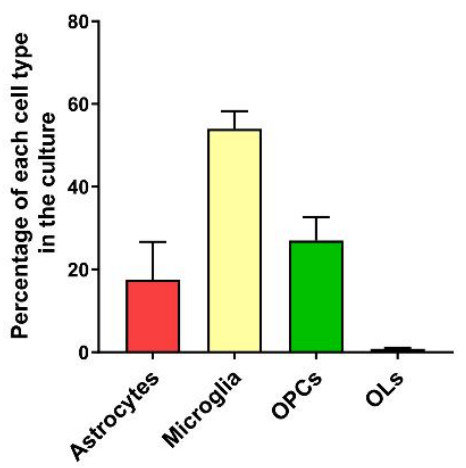

g

Cell Survival Assay

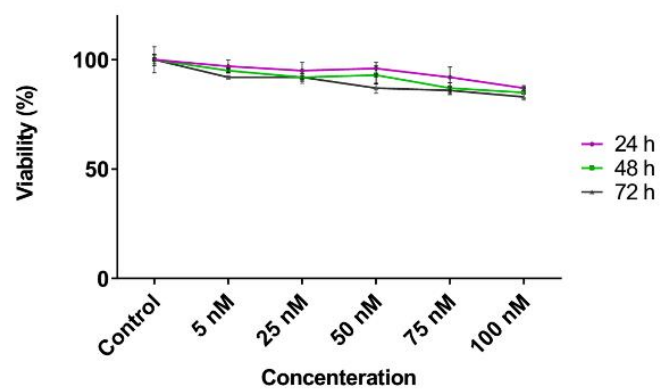


bioRxiv preprint doi: https://doi.org/10.1101/2021.08.09.455020; this version posted August 10, 2021. The copyright holder for this preprint (which was not certified by peer review) is the author/funder, who has granted bioRxiv a license to display the preprint in perpetuity. It is made available under aCC-BY-NC-ND 4.0 International license.

Figure 2

a

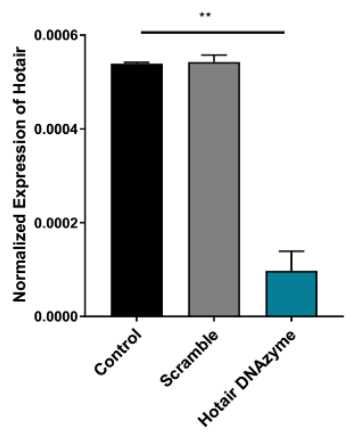

d

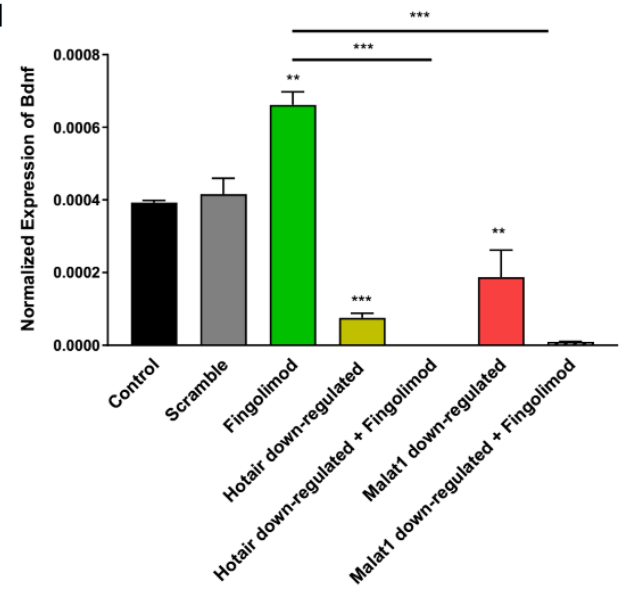

b

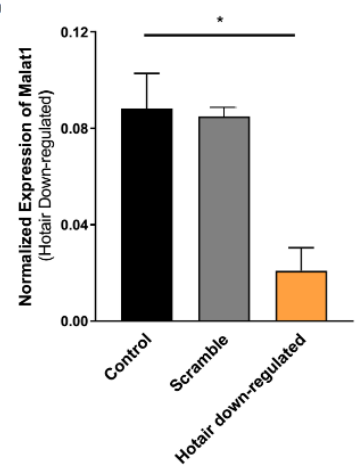

e

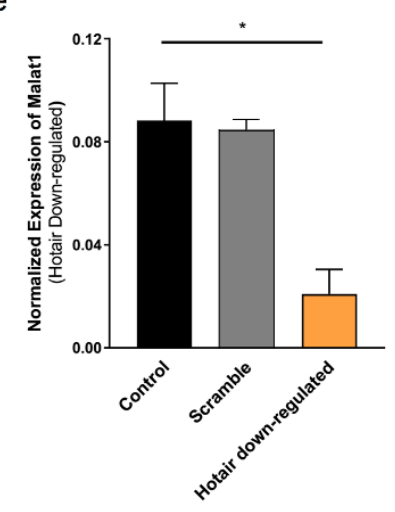

C

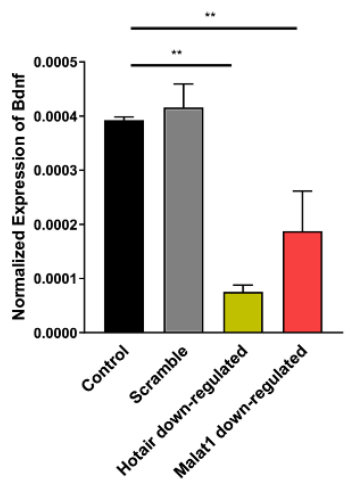

f

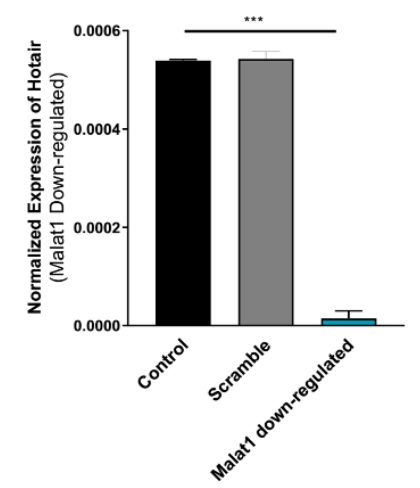


bioRxiv preprint doi: https://doi.org/10.1101/2021.08.09.455020; this version posted August 10, 2021. The copyright holder for this preprint (which was not certified by peer review) is the author/funder, who has granted bioRxiv a license to display the preprint in perpetuity. It is made available under aCC-BY-NC-ND 4.0 International license.

\section{Figure 3}

a

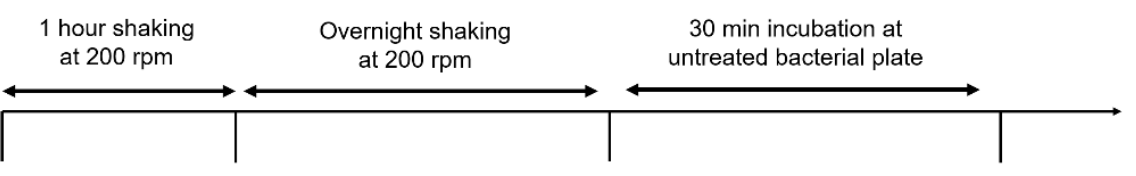

Discarding the detached microglia Collecting the medium Adding fresh medium containing detached OPCs

Astrocytes attach to the

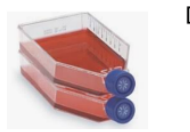
plate while OPCs remain floating

Primary glial culture

b

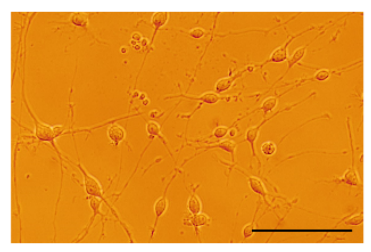

C

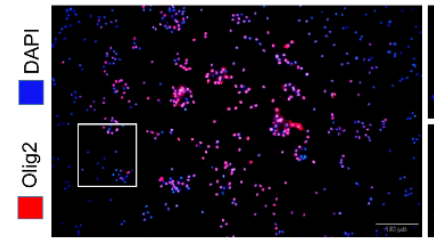

OPCs were seeded on PLL coated plates for ICC and further differentiation analyses
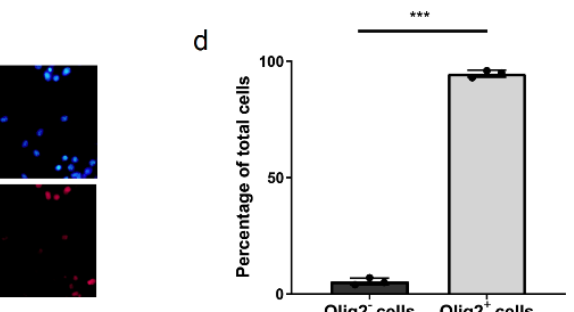
bioRxiv preprint doi: https://doi.org/10.1101/2021.08.09.455020; this version posted August 10, 2021. The copyright holder for this preprint (which was not certified by peer review) is the author/funder, who has granted bioRxiv a license to display the preprint in perpetuity. It is made available under aCC-BY-NC-ND 4.0 International license.

Figure 4
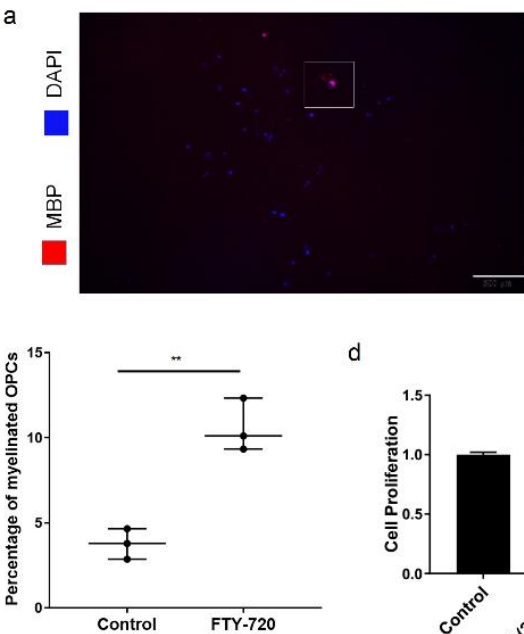

d
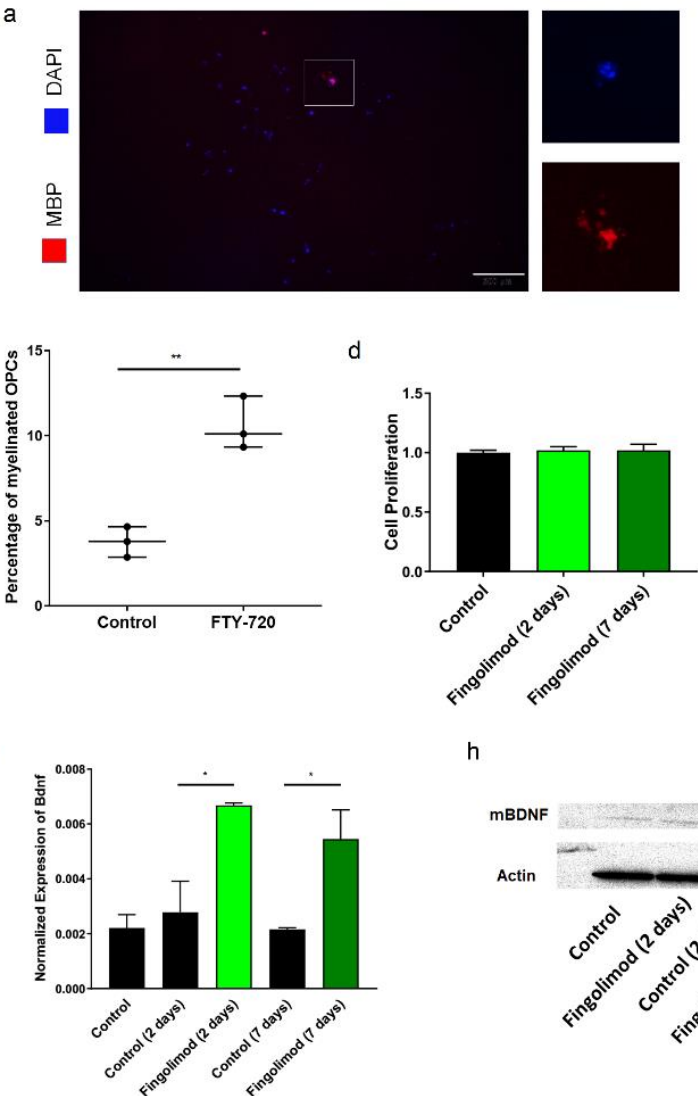

b
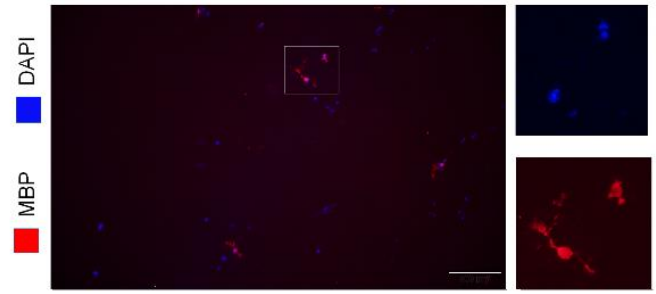

e
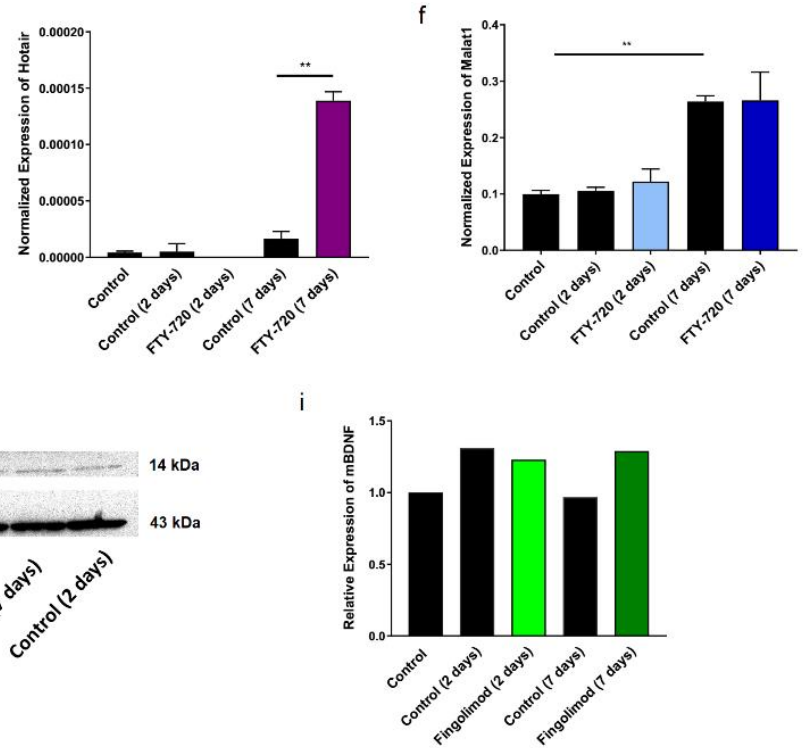


\section{Figure Captions:}

Fig. 1. Preparation of primary glial culture from $P_{0}$ rat pups' brain. a, represents the timeline that was followed to make the primary glial culture. The immunostaining demonstrates the presence of b, Iba1+ marker of microglia; c, GFAP+ marker of astrocytes; d, Olig2+ marker of oligodendrocyte lineage; and e, $\mathrm{MBP}^{+}$maker of mature oligodendrocyte cells in the prepared primary culture (scale bar $=200 \mu m, n=3) . f$, The quantification of glial cell lineage in the primary culture showed that oligodendrocyte lineage made up about $27 \%$ of the total population (error bar= standard deviation). g, Cell survival assay demonstrated that different concentrations of fingolimod treatment on the glial cells have no toxic effects at low doses; however, the cell viability reduced significantly by increasing the medicine concentration $\left({ }^{*} p<0.05,{ }^{* *} p<0.01,{ }^{* *} p<0.001,{ }^{* * *} p<\right.$ 0.0001, one-way ANOVA with Tukey's multiple comparison test, error bar= standard deviation, $\mathrm{n}$ = 3). Abbreviation: PLL= Poly L-lysin. The experiment repeated three times, and the significance level was assigned to 0.05 .

Fig. 2. Hotair and Malat1 IncRNAs can regulate Bdnf gene expression. a and Bb, The expression of Hotair and Malat1 IncRNAs was downregulated using their specific DNAzymes. c, Bdnf expression level was affected with reducing Hotair and Malat1 expression level. Obtained result showed that the Bdnf expression reduced due to a decline in expression of these two IncRNAs (unpaired t-test). d, Treatment of mixed glia cells with fingolimod increased the Bdnf gene expression; however, simultaneous downregulation of Hotair or Malat1 with fingolimod treatment not only did not induce BDNF expression but also significantly decreased its expression level. The result suggests that there is a crosstalk between Hotair and Malat1 IncRNAs in regulating Bdnf gene expression. e, a decrease in Malat1 level using its specific DNAzymes reduced the Hotair IncRNA expression level; similarly, f, reducing the Hotair level using its specific DNAzymes lessened the Malat1 expression level $\left({ }^{*} p<0.05,{ }^{* *} p<0.01,{ }^{* * *} p<0.001,{ }^{* * *} p<0.0001\right.$, unpaired t-test, error bar= standard deviation, $n=3$ ). 
Fig. 3. Isolation of OPCs from primary glial culture. a, Procedure for OPCs purification by the Shaking method. b, Light microscopy image represents isolated OPCs with bipolar morphology (scale bar $=100 \mu \mathrm{m})$. c, Fluorescence microscopy image demonstrates immunostaining for Olig2 ${ }^{+}$ cells (scale bar $=200 \mu \mathrm{m}$ ). $d$, The graph shows an efficient purification of Olig2 ${ }^{+}$cells from primary glial culture for further analyses $\left({ }^{* *} \mathrm{p}<0.001\right.$, paired t-test, $\left.\mathrm{n}=3\right)$. Abbreviation: OPCs= Oligodendrocyte precursor cells, PLL= Poly L-lysin, ICF= Immunocytochemistry.

Fig. 4. Fingolimod treatment induced OPCs differentiation. MBP/DAPI immunostaining in a, untreated, and b, Fingolimod treated OPCs represented the population of mature $\mathrm{MBP}^{+}$ oligodendrocytes (scale bar $=200 \mu \mathrm{m}$ ). c, The quantification of immunostaining results showed that the percentage of $\mathrm{Mbp}^{+}$cells was $3.7 \%$ in the control group, while it increased to $10.5 \%$ in fingolimod treated OPCs after 1 week (unpaired t-test, error bar= standard deviation, $n=3$ ). $d$, Cell proliferation assay using Resazurin salt indicated that there was no difference in the number of cells between the treated and untreated groups (one-way ANOVA with Tukey's multiple comparison test, error bar= standard deviation, $n=3)$. e, Fingolimod treatment induced the Hotair expression level after 1 week; however, $\mathrm{f}$, the fingolimod treatment did not alter the Malat1 expression level, but its expression how after 1 week in a differentiation medium $\left(\left({ }^{*} p<0.05,{ }^{* *} p<\right.\right.$ 0.01, unpaired t-test, error bar= standard deviation, $n=3) . g$, The Bdnf gene expression was elevated by fingolimod treatment; while, h, elevation of Bdnf protein expression level by western blot after 2 and 7 days of fingolimod treatment represented; i, Quantitative results of western blot did not show any significant change among different studied time periods. ( ${ }^{*} p<0.05$, unpaired ttest, $n=3)$. Abbreviation: OPCs= Oligodendrocyte precursor cells. 